BISMA

(Bisnis dan Manajemen)
Volume 13, Issue 1, 2020, 37-46

ISSN 2549-7790 (Online)

DOI: 10.26740/bisma.v13n1.p37-47

https://journal.unesa.ac.id/index.php/bisma/index

\title{
Service experience on skin care's customer attitude: the mediating role of self-congruity and functional congruity
}

\author{
Kristiningsih $^{1 *}$, Sri Hartini ${ }^{2}$, Indrianawati Usman ${ }^{3}$ \\ ${ }^{1}$ Universitas Wijaya Kusuma Surabaya, Indonesia \\ ${ }^{2,3}$ Universitas Airlangga, Indonesia
}

\begin{abstract}
This paper aimed to provide empirical evidence of the relationship between service experience, selfcongruity, functional congruity, and consumer attitude. The hypothesis in this study showed that service experience affected self-congruity and functional congruity which in turn will have an impact on consumer attitude. Data were collected through online surveys, on skin care consumer in East Java Indonesia. Hypotheses were tested using the structural equation modelling technique by WARP PLS. This paper validated the role of service experience as a mechanism facilitating the development of customer's self-congruity and functional congruity toward a skin care clinic. It also found that service experience affected in self-congruity and functional congruity, self-congruity, and functional congruity mediated the relationship between service experience and consumer attitude.
\end{abstract}

Keywords: consumer attitude; functional congruity; self-congruity; service experience

Received: February 4, 2020; Accepted: March 10, 2020; Published: October 31, 2020

*Corresponding author

Email: kristiningsih@uwks.ac.id

To cite this document:

Kristiningsih, Hartini, S., \& Usman, I. (2020). Service experience on skin care's customer attitude: the mediating role of self-congruity and functional congruity. BISMA (Bisnis dan Manajemen), 13(1), 37-46. https://doi.org/10.26740/bisma.v13n1.p37-47.

\section{INTRODUCTION}

There is a phenomenon that currently people use body care services by visiting skin care clinics, not only to fulfil physical needs but also there are various motivations that cause people to take these actions (Lee et al., 2019). Darmesta (2000) stated that one of the lifestyle orientations of society is the tendency to improve their physical performance or they wanted to look better. A large person who needs to take care of themselves to look more attractive, and the growth of women's lifestyles, ultimately providing great influence on the rapid development of the skin care industry in Indonesia.

In the current competitive skin care service industry, some of these skin care clinics are innovating to offer treatment services with the latest medical technology and natural 
ingredients. These clinics feature a blend of modernization and natural ingredients. Therefore, this skin care clinic then offers a different service experience to serve these skin care consumers (Munteanu, 2015).

The concept of customer experience or service experience is an interesting variable to be investigated further. In Brakus (2009), it is stated that there are several concepts of consumer experience, namely product experience, service experience, consumption experience, and brand experience. The service experience is an experience that occurred when consumers interacted with the physical environment of the business, its personnel, policies, and practices of the business.

In consuming a service, consumers have a subjective personal reaction. This phenomenon is called the service experience, which is an important part of customer evaluation and service satisfaction. The service experience is described as a mental state subjectively perceived by consumers. This is a concern of researchers in the field, especially researchers who are concerned with sociology, anthropology, and psychology. Otto \& Ritchie (1996) had measured service satisfaction and service experience in the tourism industry. The measurement used quantitative and qualitative methods to measure any aspects of the consumer's psychological experience when consuming services.

Furthermore, Jones \& Runyan (2012) stated that consumers experience with a brand will have a positive impact on consumer self-identification with brands. In another study, Hogg et al. (2010) show how consumer experienced as indicated by taste and distates have a direct effect on self-congruity and ideal congruity, besides affecting self-esteem. This means that besides consuming the products that they see similar to themselves, consumers will also seek to enhance or support their self-concept through a consumption process that avoids certain products that have a negative image. In other words, service experience has an impact on image congruity.

Based on their experience, the consumer will buy the product or services that they perceived as similar to their self-concept. This matching concept is known as image congruity (Sirgy, 1985). There are two dimensions of image congruity, namely self-congruity and functional congruity. Self-congruity defined as the correspondence between the concept of a person with the image of an entity or object (Jamal \& Goode, 2009), whereas functional congruity indicated a match between the functional perception of objects with functional characteristics that are considered important for consumers (Sirgy, 1999). A person can view himself as a rational or likeable person which influence them to act. Self-concept or self-image is something about the individual that is based on ideas about who they are and they want to be considered such as what (Assael, 2002). Therefore, consumers tend to choose a product/ service following their self-concept.

Congruity is a strong predictor of changes in consumer attitudes. Evaluation by consumers is a result of congruity in the consumer's frame of mind (Osgood \& Tannenbaum, 1955). Some studies supported the relationship between congruity with consumer attitudes both in the context of the product and service.

In the service context, it is also explained that self-congruity has a positive impact on consumers' evaluations of services. When consumers know that the perception of the service congruent with their self-image, consumers will assume that these services represented their 
identity, thus, helping them to shape the attitudes that favourable to these services (Kang et al., 2012).

Functional congruity shows a match between the perceived functional characteristics or performance of an object with functional characteristics that consumers wanted or consider important. Evaluation of functional attributes operated at a higher level of awareness to influence consumer behaviour. The appeal of utilitarian more effective when services are very different from the competitor and when the consumer is engaged with those services (Sirgy, 1999).

In the research conducted by Srejesh (2015), service innovativeness has a significant effect on self-congruity and functional congruity. The experience is the moderator of the subgroup that connected service innovativeness with self-congruity and functional congruity.

This study aims to analyze the effect of service experience on attitude through selfcongruity and functional congruity and its effect on consumer attitude in skin care clinic consumers.

\section{Service Experience on Self-congruity}

The experience of consumers in consuming skin care services will affect how consumers see these services by the consumer's self-concept. Jones \& Runyan (2012) stated that the consumer experience of a brand has a positive impact on consumer identification with the brand. In other words, service experience will have an impact on their self-concept with the services consumed.

H1: Service experience has a significant effect on self-congruity.

\section{Service Experience on Functional Congruity}

Consumers will experience a variety of service. The experience will affect the level of suitability what they want from such services (functional congruity) that indicate a match between the functional perception of objects with functional characteristics their wants (Sirgy, 1999). Then, Hogg et al. (2010) proved that consumer experience has a direct effect on congruity

$\mathrm{H} 2$ : Service experience has a significant effect on functional congruity.

\section{Self-congruity on Attitude}

The suitability of consumers' self-concept with the services they consumed (selfcongruity) has a positive impact on consumers' evaluation of services. When consumers know that the perception of the service congruent with their self-image, consumers attitude to this object will be favourable (Kang et al., 2012).

H3: Self-congruity has a significant effect on attitude.

\section{Functional Congruity and Attitude}

The suitability of the functional attributes that consumers want with services (functional congruity) affects consumer attitudes towards services. Utilitarian attractiveness is more effective when services are very different from competitors and consumers are deeply involved (Sirgy, 1999). 
H4: Functional congruity has a significant effect on attitude.

\section{Service Experience and Attitude}

The service experience is an important part of consumer evaluation of services (Otto \& Ritchie, 1996). Consumers who have a good experience of services will tend to provide good evaluations which are shown in a positive attitude towards services.

H5: Service experience has a significant effect on attitude.

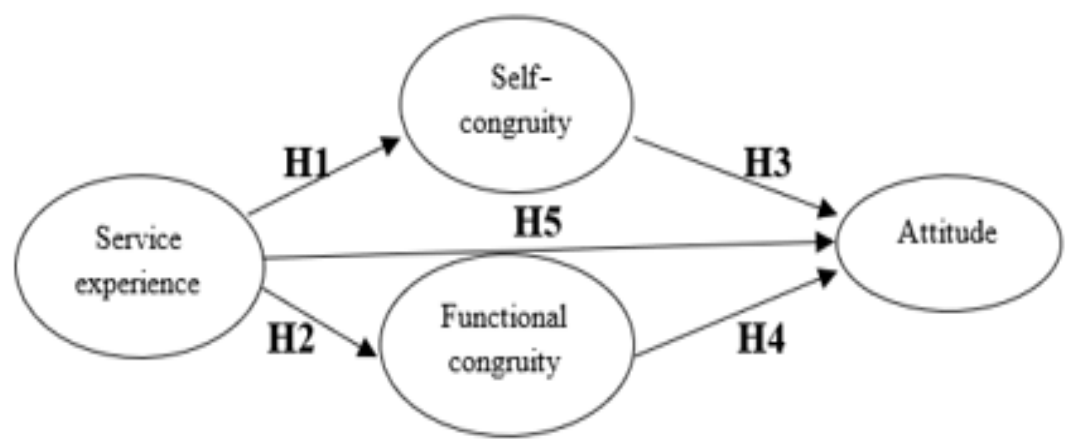

Figure 1. Analysis Model

\section{METHODS}

Quantitative analysis is the research methodology used in this research. This study emphasizes the analysis of statistical techniques and is carried out such that the meaning of the relationship between the studied variables is obtained in inferential research or the form of hypothesis testing. This analysis belongs to the causal research group since it investigates the hypothesis of the relationship between the variables examined.

The population of this research is consumers who used skin care services in East Java. The sampling technique is purposive sampling. For a particular purpose, purposeful sampling is carried out based on the characteristics set in population. The respondents are consumers of skin care services in East Java and their ages $>17$ years-old. There are selected eight skin care services preferred in East Java as a population which then selected into seven skin care that provides full skin care services.

There are 200 consumers of skin care who have been chosen as a study. Specific SEM production will require a certain number of samples. Therefore this study uses 200 samples to meet the maximum probability estimation technique. Meanwhile, through Google form, online questionnaires are distributed.

Five indicators are used to measure service experience, such as sensorial, emotional, intellectual, behavioural, and social experience (Schmitt, 1999). Meanwhile, there are two indicators are used to measure self-congruity: the subject's perception of the product-user image and the subject's perception of his or her self-image concerning the product-user image (Sirgy et al., 1997). Furthermore, four indicators are used to measure functional congruity: convenience, customer service, performance or quality, and reliability (Mangleburg et al., 1998).

To test the causal relationship between exogenous variables (service experience, selfcongruity, and functional congruity), to endogenous variables (consumer attitude), Structural 
Service experience on skin care's customer attitude: the mediating role of self-congruity and functional congruity

Equation Model (SEM) with the WARP Partial Least Square version 6.0 program is used. SEM analysis is carried out to see the direction and significance of the magnitude/ path coefficient of service experience, self-congruity, functional congruity, and consumer attitude.

\section{RESULT AND DISCUSSION Result}

The results of the study are shown by the results of the validity, reliability, goodness of fit, and path coefficient test results of each variable being tested. To test the validity of the discriminant, apart from cross-loading, the thing that should also be considered is the correlation between variables by looking at the square root of AVE. Table 1 shows that the AVE root in the diagonal column is higher than the correlation between latent variables in the column other than the diagonal. Discriminant validity has been fulfilled. This means that the question item of each research variable measures the construct of the variable under study.

Table 1. Laten Correlation Output

\begin{tabular}{ccccc}
\hline Variable & SE & SC & FC & ATS \\
\hline Service Experience & 0.725 & 0.528 & 0.589 & 0.560 \\
Self-congruity & 0.528 & 0.786 & 0.653 & 0.526 \\
Functional Congruity & 0.589 & 0.653 & 0.752 & 0.671 \\
Attitude toward Service & 0.560 & 0.526 & 0.671 & 0.875 \\
\hline
\end{tabular}

Table 2. Latent Variable Coefficients for Composite Reliability and Cronbach's Alpha

\begin{tabular}{ccccc}
\hline Test & SE & SC & FC & ATS \\
\hline R-squared & & 0.290 & 0.347 & 0.515 \\
Composite Reliability & 0.847 & 0.889 & 0.886 & 0.908 \\
Cronbach's Alpha & 0.774 & 0.844 & 0.844 & 0.847 \\
Avg. Var. extract & 0.526 & 0.617 & 0.565 & 0.766 \\
\hline
\end{tabular}

The instrument can be said to be reliable if it has a composite reliability value $>0.70$ and Cronbach's Alpha must be $>0.60$ (Sholihin \& Ratmoko, 2013). From Table 2, it can be seen that the seven constructs have value composite reliability $>0.70$ with the highest value of 0.908 which is the construct of attitude toward skin care and the lowest value of 0.847 which constructs service experience. Furthermore, it can be seen that the seven constructs have a Cronbach's Alpha value $>0.60$ with the highest value 0.847 , namely the attitude toward skin care construct and the lowest value of 0.774 , which is the service experience construct. Hence, it can be stated that all constructs in this study are acceptable and reliable.

The fit and indices and p-value model section displays the results of three indicators, namely the Average Path Coefficient (APC), average R-squared (ARS), and average variance inflation factor (AVIF). The p-value is given for the APC and ARS indicators calculated by estimating sampling and Bonferroni like correction. This is necessary because they are calculated as parameter averages.

The p-value for APC and ARS must be $<0.05$ or significant. Also, AVIF as an indicator of multicollinearity must be less than five. The result shows that the goodness of fit model criteria has been met, namely with an APC value of $0.389, \mathrm{p} \leq 0.001$ and an ARS value of 0.384 $\mathrm{p} \leq 0.001$. AVIF value $=1.803$ also meets the criteria. 
The relationship between latent variables in the research model can be seen from the results estimated path coefficients and the significance level (p-value), which is that the significance level used is $5 \%$. To test the proposed research hypothesis, it can be seen from the $\mathrm{p}$-value. If the $\mathrm{p}$-value $<0.05$, then $\mathrm{H} 0$ is rejected and $\mathrm{Ha}$ is accepted. The estimation results of path coefficients to test the strength of the influence between variables and to explain the firmness of the relationship between variables can be seen in Figure 3 .

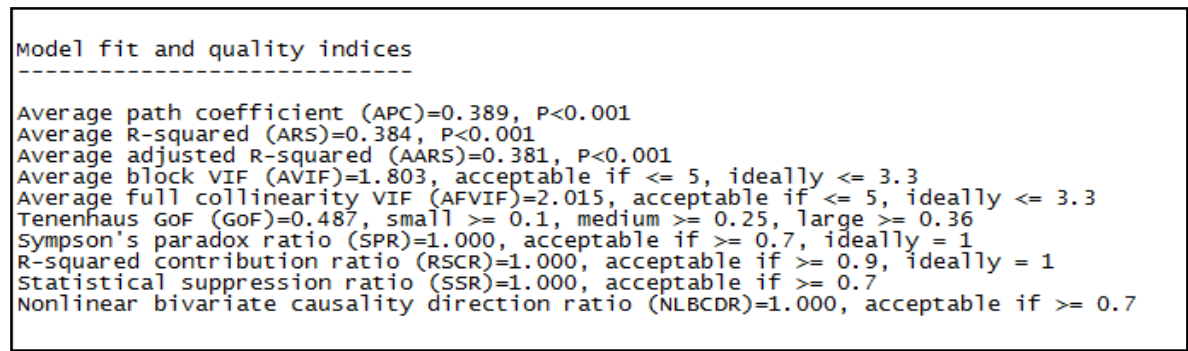

Figure 2. Model Fit and Quality Indices

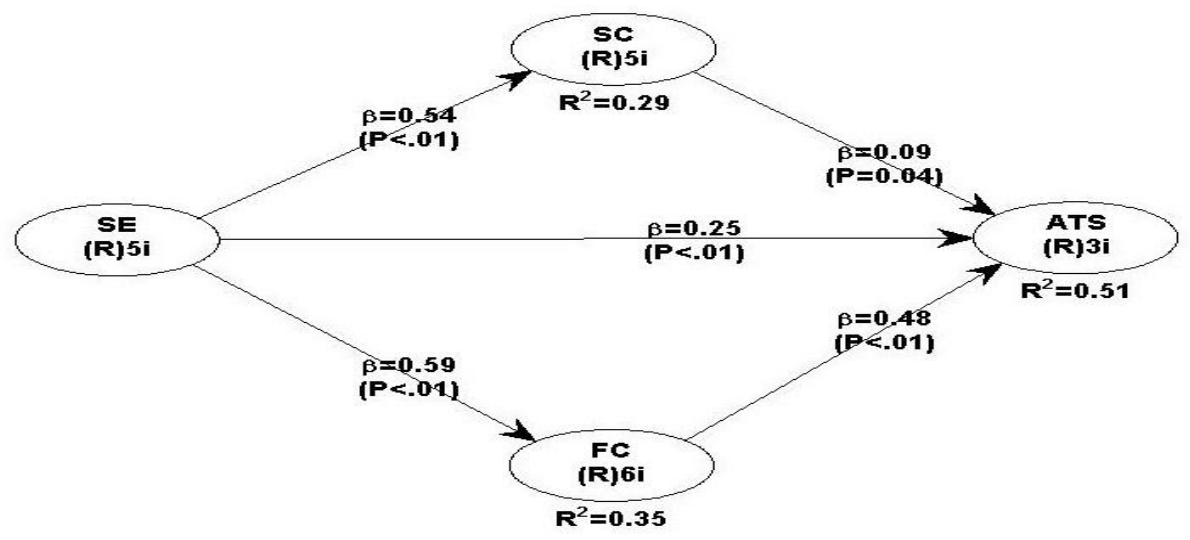

Figure 3. Estimated Output

According to Table 3, the VAF value for the self-congruity variable is equal to 0.169 or $<20 \%$, so this shows that self-congruity is not a mediation variable. VAF for functional congruity variable is equal to 0.531 or $>20 \%$, so this shows the functional congruity as partial mediation. This partial mediating effect indicates that functional congruity is not the only one that can be mediating variables in this model.

\section{Discussion}

This study demonstrates that service experience has a significant effect on self-congruity, so the hypothesis that service experience has a positive effect on self-congruity is accepted. The result explains that the experience as feeling happy, remembering, feeling safe, get new experiences, and taste a relaxed obtained by consumers when getting services of skin care can improve the suitability of these services with the self-concept of consumers who care about health, modern, and classy. When consumers have a good experience while consuming skin care services, that experience will be captured by consumers as something that is following the self-concept of consumers who care about skin health. This statement supports research conducted by Jones \& Runyan (2012) which states that the consumer experience of a brand will have a positive impact on consumer self-identification with that brand. 
Service experience on skin care's customer attitude: the mediating role of self-congruity and functional congruity

Table 3. Calculation of Variance Accounted For (VAF)

\begin{tabular}{lc}
\hline Relationship & VAF \\
\hline Self-congruity & \\
Indirect effect $=0.539 \times 0.094(\mathrm{SE} \rightarrow \mathrm{SC}=0.539 ; \mathrm{SC} \rightarrow \mathrm{ATS}=0.094)$ & 0.051 \\
Direct influence $(\mathrm{SE} \rightarrow \mathrm{ATS} ;$ without entering the mediating variable $=0.25)$ & 0.25 \\
Effect total $=0.051+0.25$ & 0.3006 \\
$\mathrm{VAF}=$ indirect effect $/$ total effect $=0.051 / 0.3006$ & 0.169 \\
Functional Congruity & \\
Indirect effect $=0.589 \times 0.478$ & 0.282 \\
$(\mathrm{SE} \rightarrow \mathrm{FC}=0.589 ; \mathrm{FC} \rightarrow \mathrm{ATS}=0.478)$ & 0.25 \\
$\begin{array}{l}\text { Direct influence } \\
(\mathrm{SE} \rightarrow \mathrm{ATS} ; \text { without entering the mediating variable }=0.25)\end{array}$ & 0.531 \\
Total effect $=0.282+0.25$ & 0.531 \\
$\mathrm{VAF}=$ indirect effect $/$ influence total $=0.282 / 0.531$ & \\
\hline
\end{tabular}

This study also verifies that the service experience has a significant effect on functional congruity so that the hypothesis which stated that the service experience has a positive effect on functional congruity is accepted. The result explains that based on consumer experiences that consumers got when visited skin care services, consumers feel that the service can improve the suitability of these services with the attributes that consumers wanted. The services which provided benefit to make the physical appearance better. This statement is in line with research conducted by Hogg et al. (2010) which shows how to taste and distastes have a direct effect on congruity, in addition to influencing self-esteem. This means that when the experience of consuming skin care services is good, consumers will assess the compatibility between the benefits that consumers want with the functional attributes that the skin care clinic offered.

Furthermore, self-congruity has a significant effect on attitude toward skin care. When consumers see the suitability of services with their self-concept of consumers who concern about skin health, then the consumer's attitude towards these services is shown well, the consumers will believe in the skin care service, like it, and plan to reuse it. This statement is in line with research conducted by Sirgy (1985) and Srejesh (2015) which stated that selfcongruity affects consumer attitudes.

The study also reveals that functional congruity has significant effects on attitude. When consumers assess the suitability between services attributes offered by the desired benefit consumers, consumers prefer those services and be positive. This statement supports research conducted by Sirgy (1985) and Srejesh (2015) which stated that consumer functional congruity affects attitudes and behaviour.

This study also stated that service experience has a significant effect on attitude toward skin care. When consumers are consuming services and have a good experience when consuming them, there will be a feeling of love and a positive attitude towards the skin care service. It is in line with research conducted by Srejesh (2015) which stated that if consumers have a good (strong) experience of a service, it will improve consumer attitudes towards that service.

\section{Managerial Implications}

This research provides an understanding to marketing practitioners about how to form consumer attitudes on an object, especially if the previous consumer's attitude shows 
unfavourable things. Then, through the formation of attitudes based on self-congruity and functional congruity, consumers can form a better attitude. Besides, this research also provides an understanding to marketing practitioners that the consumer experience carried out by a company is important to create a good image congruity for the services produced, if consumers judge the experience obtained from good services, it will create a positive consumer attitude.

\section{CONCLUSION}

This research verifies that service experience has a positive effect on self-congruity and functional congruity. This study also concluded that self-congruity has a positive effect on consumer attitude, but do not become a mediating variable between service experience and consumer attitude. Functional congruity has a positive effect on consumer attitude. This study also concludes that service experience has a positive effect on consumer attitude. In this study, functional congruity is proven to be a partial mediating variable between service experience and consumer attitude. It is necessary to study further other mediating variables that affect consumer attitudes, such as brand trust or behavioural intention.

\section{REFERENCES}

Assael, H. (2002). Consumers Behaviours and Marketing Action (3rd ed.). Boston Massachussets: Kent Publishing Company.

Brakus, J.J., Schmitt, B.H., \& Zarantonello, L. (2009). Brand experience: What Is It? How Is It Measured? Does It Affect Loyalty?. Journal of Marketing, 73(3), 52-68. https://doi.org/10.1509/jmkg.73.3.052.

Darmesta, B. S. (2000). Manajemen Pemasaran: Analisa Perilaku Konsumen (1st ed.). Yogyakarta: BPFE Yogyakarta.

Hair, J. F. (2010). Multivariate Data Analysis (7th ed.). New Jersey, USA: Pearson Prentice Hall.

Hair, J. F., Black, W. C., Babin, B. J., \& Anderson, R. E. (2013). Multivariate Data Analysis (7th ed.). New Jersey, USA: Pearson Prentice Hall.

Hogg, M. K., Banister, M. (2010). Dislikes, Distastes and the Undesired Self: Conceptualising and Exploring the Role of the Undesired End State in Consumer Experience. Journal of Marketing Management, 17(1), 73-104. https://doi.org/10.1362/0267257012571447.

Jamal, A. \& Goode, M. M. H. (2009). Consumers and brands: a study of the impact of selfimage congruence on brand preference and satisfaction. Marketing Intelligence \& Planning, 19(7), 482-492. https://doi.org/10.1108/02634500110408286.

Jones, R. P. \& Runyan, R. C. (2013). Brand experience and brand implications in a multichannel setting. Brand experience and brand implications in a multi-channel setting, 23(3), 265-290. https://doi.org/10.1080/09593969.2013.781531.

Kang, J., Tang, L., Yup, J., \& Bosselman, R. H. (2012). International Journal of Hospitality Management Understanding customer behavior in name-brand Korean coffee shops: The role of self-congruity and functional congruity. International Journal of Hospitality Management, 31(3), 809-818. https://doi.org/10.1016/j.ijhm.2011.09.017. 
Service experience on skin care's customer attitude: the mediating role of self-congruity and functional congruity

Lee, J.E., Goh, M.L. \& Mohd Noor, M.N.B. (2019). Understanding purchase intention of university students towards skin care products. PSU Research Review, 3(3), 161-178. https://doi.org/10.1108/PRR-11-2018-0031.

Maholtra, N. K., \& Peterson, M. (2009). Basic marketing research. A decision-making approach. New Jersey, USA: Pearson/ Prentice Hall.

Mangleburg, T. F., Sirgy M. J., Grewal, D., Hatzios, M., Axsom, D., Claiborne, C.B., \& Bogle, T. (1998). The moderating effect of prior experience in consumers' use of user-image based versus utilitarian cues in brand attitude. Journal of Business and Psychology, 13(1), 101-113. https://doi.org/10.1023/A:1022927201433.

Munteanu, C. C. (2015). Competitive differentiation through brand extensions in the era of hyper competition. Romanian Economic Journal, 18(55), 57-70.

Osgood, C. E. \& Tannenbaum, P. H. (1955). The Principle of Congruity in The Prediction of Attitude Change. Psychological Review, 62(1), 42-55. https://doi.org/10.1037/h0048153.

Otto, J.E. \& Ritchie, J.R.B. (1996). The service experience in tourism. Tourism Management, 17(3), 165-174. https://doi.org/10.1016/0261-5177(96)00003-9.

Schmitt, B. (1999). Experiential marketing. Journal of Marketing Management, 15(1-3), 5367. https://doi.org/10.1362/026725799784870496.

Sekaran, U. \& Bougie, R. (2011). Business Research Methods: A skill-building approach. Chichester: John Wiley\& Sons Ltd.

Sholihin, M. \& Ratmono, D. (2013). Analisis SEM-PLS Dengan WarpPLS 3.0. Yogyakarta: Penerbit Andi.

Sirgy, M. J. \& Johar, J. S. (1999). Toward An Integrated Model of Self-Congruity and Functional Congruity. European Advances in Consumer Marketing, 4, 252-256.

Sirgy, M. J. (1985). Using Self-Congruity and Ideal Congruity to Predict Purchase Motivation. Journal of Business Research, 13(3), 195-206. https://doi.org/10.1016/01482963(85)90026-8.

Sirgy, M. J. \& Danes, J.E. (1982). Self-image/ product-image congruence models: Testing selected models. ACR North American Advances, 9, 556-561.

Sirgy, M. J., Grewal, D., Mangleburg, T. F., Park, J. O., Chon, K. S., Claiborne, C. B., \& Berkman, H. (1997). Assessing the predictive validity of two methods of measuring selfimage congruence. Journal of the academy of marketing science, 25(3), 229.

Srejesh, S. A. M. D. S. (2015). The impact of customer's perceived service innovativeness on image congruence, satisfaction and behavioral outcomes. Journal of Hospitality and Tourism Technology, 6(3), 288-310. https://doi.org/10.1108/JHTT-10-2014-0061. 


\section{Appendix 1. Questionnaire}

The following questions are used to assess the skin care service business that you visited in the last 2 months. Choose the most appropriate answer with a mark $(\sqrt{ })$, is the most appropriate answer.

\begin{tabular}{|c|c|c|c|c|c|c|}
\hline No & Statement & SS & $\mathrm{S}$ & $\mathrm{N}$ & TS & STS \\
\hline & Service Experience & & & & & \\
\hline 1 & $\begin{array}{l}\text { You experience a happy feeling when enjoying the services provided at } \\
\text { this skin care clinic. }\end{array}$ & & & & & \\
\hline 2 & You enjoy the new experience of this skin care service. & & & & & \\
\hline 3 & $\begin{array}{l}\text { You get to experience a relaxed/ comfortable (relax) while in this skin } \\
\text { care clinic. }\end{array}$ & & & & & \\
\hline 4 & $\begin{array}{l}\text { You experience a feeling of security when using the products and } \\
\text { treatments in this skin care. }\end{array}$ & & & & & \\
\hline 5 & $\begin{array}{l}\text { You feel that you have changed for the better in terms of physical } \\
\text { appearance (more beautiful/ handsome/ more well-groomed) when you } \\
\text { get services at this skin care service. } \\
\text { Self-congruity }\end{array}$ & & & & & \\
\hline 1 & $\begin{array}{l}\text { This skin care service is consistent with what you see on yourself as a } \\
\text { modern person. }\end{array}$ & & & & & \\
\hline 2 & $\begin{array}{l}\text { This skin care service reflects/ reflects who you are as a person who cares } \\
\text { about the health. }\end{array}$ & & & & & \\
\hline 3 & This skin care service reflects your self-image as a classy person. & & & & & \\
\hline 4 & $\begin{array}{l}\text { Other consumers of this skin care service have the same self-image as } \\
\text { you. }\end{array}$ & & & & & \\
\hline 5 & $\begin{array}{l}\text { Other consumers of this skin care service are similar to your typical. } \\
\text { Functional Congruity }\end{array}$ & & & & & \\
\hline 1 & $\begin{array}{l}\text { This skin care Clinic is offered provides the benefits according to what } \\
\text { you want (clean, healthy, white, toned skin, etc.). }\end{array}$ & & & & & \\
\hline 2 & $\begin{array}{l}\text { This skin care Clinic offered according to the benefits you want to look } \\
\text { better physically (beautiful, handsome). }\end{array}$ & & & & & \\
\hline 3 & $\begin{array}{l}\text { This skin care Clinic that is offered by your desire to appear more } \\
\text { confident in the community in your environment. }\end{array}$ & & & & & \\
\hline 4 & $\begin{array}{l}\text { This skin care Clinic offered to your liking for easel in more exist in your } \\
\text { community. }\end{array}$ & & & & & \\
\hline 5 & $\begin{array}{l}\text { This skin care Clinic offered following your desire to be able to relax } \\
\text { from the routine of daily activities. }\end{array}$ & & & & & \\
\hline 6 & $\begin{array}{l}\text { This skin care Clinic offered under your wishes for recreational facilities } \\
\text { to fill your spare time }\end{array}$ & & & & & \\
\hline & Attitude toward skin care. & & & & & \\
\hline 1 & $\begin{array}{l}\text { You believe in the benefits of the skin care services offered based on } \\
\text { what you know and see. }\end{array}$ & & & & & \\
\hline 2 & Overall, you like this skin care service. & & & & & \\
\hline 3 & You plan to reuse this skin care service in the future. & & & & & \\
\hline
\end{tabular}

